\title{
WOMEN IN PAID EMPLOYMENT - THE CARE FACTOR
}

\author{
Suzy Morrissey \\ Victoria University of Wellington
}

\begin{abstract}
63.7\% of women are now in some form of paid employment in New Zealand, which is in line with the OECD average of 65\%. However, of those women, approximately a third in parttime paid employment and women make up over two-thirds of all part-time workers.

One of the most cited reasons for women's limited participation in, or absence from, the labour market is the cost and availability of childcare. In New Zealand, as in many other countries, mothers still undertake the vast majority of care for children. This paper examines the childcare situation in New Zealand. Taking a broad perspective of what is captured by the term 'childcare', it outlines the various types of government support currently provided to children up to age 13, and summarises the total cost of funding.
\end{abstract}

The purpose of the paper is to collate information about the range of services provided by the government which incorporate an element of care. This information can be analysed by academics and policy makers to determine whether the services currently provided are efficient and effective, and meets the needs of parents.

The paper also raises two issues for further consideration, which it does not address itself. Firstly, the various mechanisms for government support, in terms of demand-led and supplyside funding, and whether they should be targeted or universal. Secondly, the types of childcare which are not government funded - the informal childcare provided by family, particularly grandparents and older siblings, and friends. These areas may be of relevant future research, particularly if change to the current situation is desired. 


\section{Introduction}

$63.7 \%$ of women are now in some form of paid employment in New Zealand (Ministry of Women's Affairs, a), which is just below the OECD average of 65\% (OECD, 2012). However, of those women, a third are in part-time paid employment (33.8\%) and women represent over two-thirds of all part-time workers (69.42\% - Statistics New Zealand, 2014). The OECD average for women in part-time employment is $46.5 \%$ (European Commission, 2012).

The prevalence of part-time work may not be women's preference, based on the under-employment rate, which is currently $6.1 \%$ for women, as compared to just $2.6 \%$ for men (Statistics New Zealand, 2014). It has been previously noted that women are underutilised in the New Zealand labour market (Hall, 2008; Flynn and Fromm, 2012). Currently, there is particular under-utilisation in Canterbury, where women are indicating that they want to work and are available to do so (Ministry of Women's Affairs, 2013). A preference for increased participation by women has also been noted in other OECD countries (Jaumotte, 2013:5).

There are a number of reasons why a government may wish to support increased female labour market participation. Firstly, it is strongly linked to a reduction in inequality and poverty. A government paper on reducing inequality noted the importance of 'addressing the barriers to employment and increasing incentives to find employment for disadvantaged groups' (Ministry of Social Development, 2003). International research indicates that, in a two parent household, 'having both partners in paid work offers strong protection against poverty, even when wages are low' (Lawton and Thompson, 2013:4). Other research claims that '(S)upporting parents into work is key to reducing child poverty rates' (Ben-Galim et al, 2014:49) and that '(f)amilies where parents work experience a significantly lower risk of childhood poverty' (Thompson \& Ben-Galim, 2014:2).

Secondly, an increase in female labour market participation could have a significant impact on our economy. In 2011, a Goldman Sachs report suggested that a 10\% increase in New Zealand's gross domestic product (GDP) could be achieved by 'closing the male and female employment rates' (Goldman Sachs, 2011). Similar claims have also been made for other developed countries such as Australia where it was suggested that a $6 \%$ increase in employment would result in an additional $\$ 25$ billion of gross domestic product 
(Summers, 2013). Further afield, it is estimated that a $5 \%$ increase in maternal employment rates in the UK would result in additional $£ 750$ million tax revenue and benefit savings every year (Ben-Galim et al, 2014:48). However, it is important to note that these estimates do not attach a value to the unpaid work carried out by women who are potentially under-employed (see Waring, 1988 for discussion of valuing unpaid work by women), and such work would still need to be undertaken.

Thirdly, liberal feminist research indicates the importance of women being in paid employment. It is argued that gender equality can best be achieved 'through paid work, rather than despite it', because people are shaped deeply by their work, to the extent that 'we are what we do for a living' (Schultz: 2000: 1883, 1884). Schultz suggests that paid work is important because it is a fundamental part of 'citizenship, community and even personal identity' (Schultz: 2000: 1886). From a practical perspective, the ability to remain in or return to paid work provides 'longer-term benefits of greater employment experience and higher subsequent wage levels for mothers' (Paull, 2012:21).

Childcare is generally understood to be one of the most, if not the most important requirement in allowing women to (re-)enter the paid workforce, and this has been the case for many years (Women's Business Council, 2014:14; Lawton and Thompson, 2013:5; World Economic Forum, 2013:63; Plantenga \& Remery, 2013:7; Young, 1994:552). In New Zealand, women are responsible for the vast majority of care of children with $12 \%$ of partnered fathers not undertaking any childcare on an average weekday (Statistics New Zealand, 2013:11) and 'Mother-only' care' representing 'almost seven times the proportion of 'father-only' care on weekdays' (Statistics New Zealand, 2013:20).

The relationship between childcare obligations and labour market participation is acknowledged by government. The stated intention for the Out of School Care Programmes (known as 'OSCAR' out-of-school care and recreation) is 'to achieve increased opportunities for parents and caregivers to gain and sustain employment' (Vote Social Development, 2014:171).

However, quality childcare does more than provide opportunities for parents to participate in paid work or study. With respect to the impact on the individual child, there are a number of reasons why a government may wish to encourage children to participate in formal childcare, as provided by Early Childhood Education (ECE) services. The 
Ministry of Education states that '( $t$ )he Government is funding 20 Hours ECE because it believes that giving young children the best possible start in life is vitally important, and that quality ECE builds the lifelong foundations of successful learning' (Ministry of Education, a). ECE participation improves children's school-readiness, increasing the likelihood that they will do well at school. Advocates call for governments to 'invest in early-years education and care in order to reduce inequalities in school-readiness, and to tackle the high social and economic costs of entrenched disadvantage that start at the very beginning of children's lives' (Ben-Galim et al, 2014:6). In addition, research indicates some childcare can have 'long-term social and behavioural developmental benefits for children that can last up to at least age 14 and possibly into later life' (Paull, 2012:21).

\section{Outline of paper}

This paper examines the childcare situation in New Zealand and is in three parts. The first part outlines the various types of government support for childcare, taking a broad perspective of what is captured by the term 'childcare'. It also identifies the financial cost to the government of providing those services.

The second and third parts identify potential areas for further consideration, which are not considered in depth in this paper. Part two raises the question of funding. It provides a brief summary of the relevant considerations in choosing between demand-led and supply-side funding options, including some international experiences, and notes the policy choice between universal and targeted funding. Part three highlights childcare which is not paid for by the government. This is informal childcare, generally provided by non-parent family members, particularly grandparents and older siblings, and friends.

\section{Part One - Childcare in New Zealand}

Findings

Adopting a broad perspective of what is captured by the term childcare, the estimated costs in the 2014/15 financial year of the various direct government funding provided for childcare is $\$ 10.9$ billion. Full details are provided in Appendix 1. Due to the lack of detailed information, some appropriations have been included in full, even though only part of the expenditure will be on childcare, as indicated in the 'comment' section. 
However, the table is intended to provide indicative figures, rather than an exact dollar calculation.

Clearly, a number of the childcare initiatives shown in the table may also correctly be considered to have an alternative primary focus. In the case of school for children aged 6 to 13 , it is clear that the primary focus is education. However, as it is against the law for children under 14 to be unattended 'without making reasonable provision for the supervision and care of the child, for a time that is unreasonable or under conditions that are unreasonable having regard to all the circumstances' (Summary Offences Act 1981, Section $10 \mathrm{~B}$ ) it is reasonable to suggest that a secondary purpose of care is also present.

At the other end of what is arguably a spectrum of care, there are payments to new parents in the form of paid parental leave (PPL). Funding for state care and protection provided by Child, Youth and Family and benefits such as the Unsupported Child and Orphan's benefit are also payments made solely to cover the cost of care of children. In between, there are a range of income-tested payments administered by the Ministry for Social Development (MSD) and Inland Revenue (IR) to support working and non-working parents. All payments will reflect an element of care, whether undertaken by parents or as a reimbursement for external care providers.

The range of care and other purposes reflected in the $\$ 10.9$ billion funding, and the appropriations which fund them, are represented as Figures 3 and 4 in Appendix 2. Another way of characterising the various types of government support for childcare is to identify whether it provides support to parents who are in work, or out of work. This is shown by initiative in Figure 1, and with costs allocated in Figure 2. 
Figure 1 - Care support characterisation (by initiative)

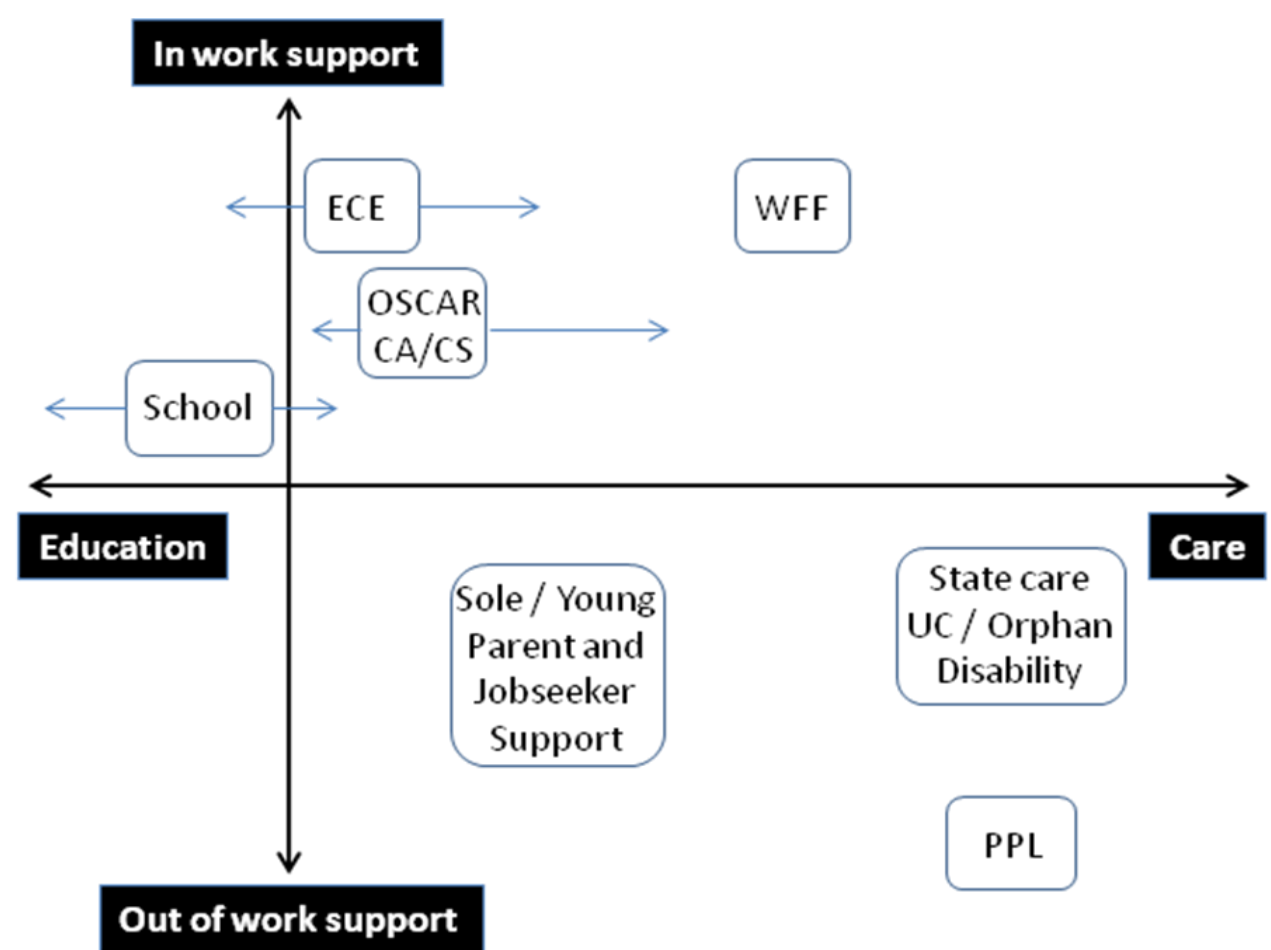

Figure 2 - Care support characterisation (by cost)

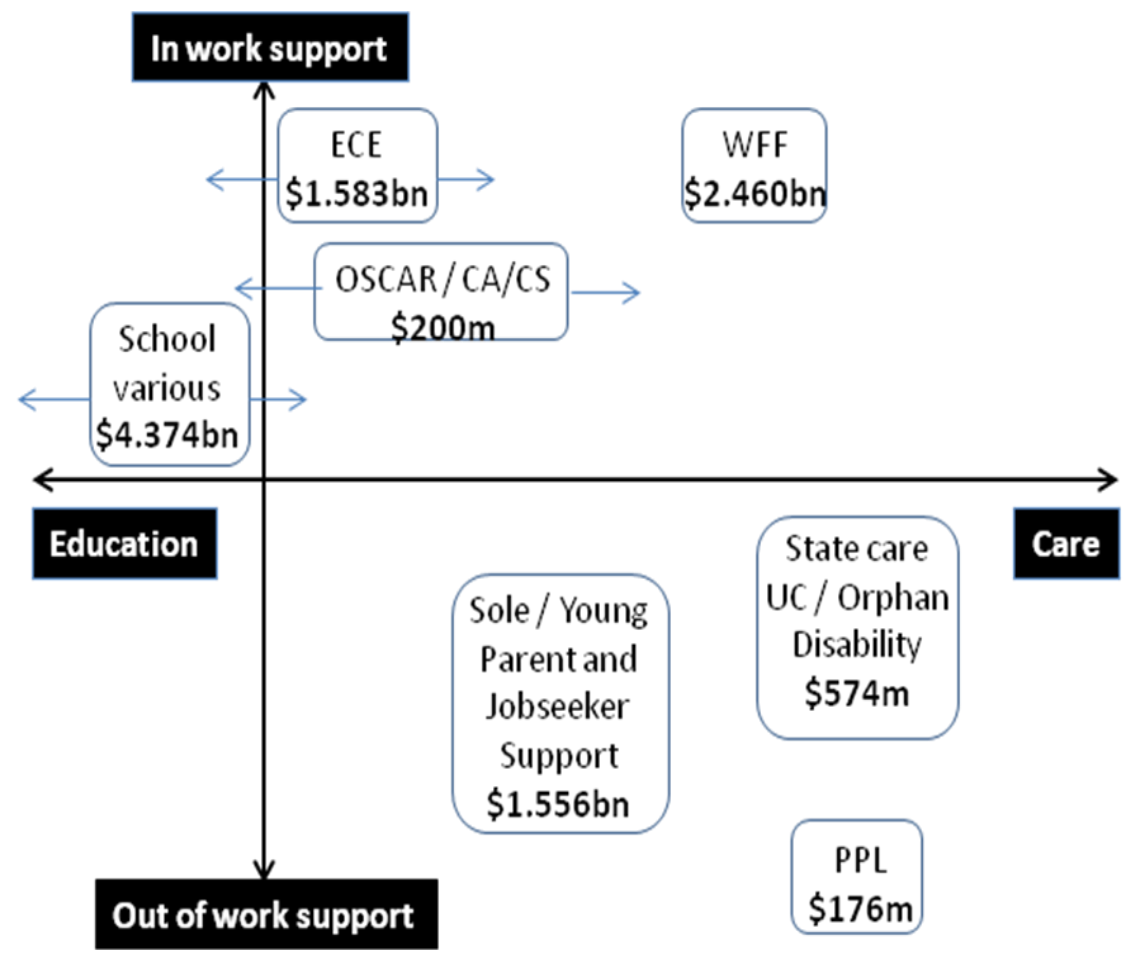


When is education not just education?

This simple depiction starts to highlight the potential questions about the role of schools in modern society. It is likely that to a number of parents, school provides an element of care, not just education. In particular, after-school and holiday programmes are often essential in order for parents to participate in the labour market or in education or training. Devoid of these programmes, parents have limited time without care obligations. The same is also true of early childhood education. Overall, we know that the traditional school hours of $9 \mathrm{am}-3 \mathrm{pm}$ and term time only care is no longer sufficient for parents today. However, not all parents have access to the level of care they require.

Firstly, not all schools provide after-school and holiday programmes. Such programmes give play opportunities, rather than education, so it may not be considered the role of schools to provide them. However, if schools are now considered to have a care role, even if this view is currently only held by parents, does the State need to start providing other services at schools as well as education? Is there a requirement for the State to provide these services directly, or to provide more support for parents to be able to access them from the private or not-for-profit sectors? Currently, both for-profit businesses and not-for-profit entities are running after-school and holiday programmes from selected school premises (for example, sKids, Oscar Network and many others). The current level of financial support from the government for these services is approximately $\$ 200$ million per annum, represented by the Childcare Assistance and after-school care OSCAR appropriations, both of which are administered by the Ministry of Social Development. This expenditure represents less than $2 \%$ of the total $\$ 10.9$ billion to be spent on childcare this financial year.

Secondly, access to early childhood education may be harder for some parents than others. The government has a target that "by 2016, 98\% of children starting school will have participated in quality early childhood education" (Ministry of Education, b). In March 2014, 93.56\% of children starting school had participated in early childhood education (Education Counts, a). However, those from 'lower socio-economic areas' have 'substantially less participation' in ECE than new entrants at the highest decile schools (Salvation Army, 2011). Participation also varies by ethnicity, between 2000-2013, 'European children were the most likely to attend ECE across the period, with participation rates reaching 98.2\%, while Mãori and Pasifika children continued to be the least likely to 
attend' (Education Counts, b). To address this issue, the government introduced an ECE Participation Programme to support participation particularly among Māori and Pasifika children, and children from low socio-economic communities. At $\$ 24$ million per annum, this funding represents $1.5 \%$ of the total government spending on ECE. As quality ECE is recognised to have positive effects for disadvantaged children, there is a policy question as to whether spending on this area should be increased. The issue of targeted funding will be considered in part two of this paper.

Another factor in participation is the availability of services at a time and in a location that suits the needs of the parents. The hours during which childcare is provided is often 'during and around regular working hours' which fails to support '(P)arents who work on evenings and weekends' (Ben-Galim et al, 2014:32). This was highlighted in a New Zealand survey of parents working non-standard hours which revealed a desire for 'more flexibility in how childcare centres operated' for example being able to 'choose different days each week at the centre to fit their shift roster' (Families Commission, 2008a:44). It was also raised in the most recent Childcare Survey, with 'a lack of available care on the days or at the times needed' noted as an issue by $29.2 \%$ of parents who were either currently working or wanting to work (Statistics New Zealand, 2010:15). The issue now has private sector involvement, with Countdown supermarkets to be the first pilot company in a Sustainable Business Council initiative to develop an 'innovative new model of childcare' which will be a 'flexible, adaptable and affordable solution that's aligned with job locations, transport and community services' (Sustainable Business Council). This recognises that 'entry-level jobs can require working outside standard business hours, or have rosters that make childcare provision a major challenge' making it difficult for sole parents to enter and stay in the workforce.

This 'childcare gap' as the 'discrepancy between the demand for and provision of childcare' (Ellingsaeter and Gulbrandsen, 2007:649) is known, is experienced internationally, as well as in New Zealand. From an economic perspective, the market for childcare during non-standard hours may be too thin to be viable without government support. Similarly, in terms of geography, the private sector has established childcare centres in 'economically viable communities' resulting in an 'uneven distribution of facilities' for children in New Zealand (Salvation Army, 2011:36). This is reflected in a lack of places for children in rural areas where $10.2 \%$ of children are not attending out-of-school services due to 'a lack 
of available places, lack of availability or lack of provision at times needed' (Statistics New Zealand, 2010:9).

Finally, it is important to note that while all ECE services 'must meet minimum standards of education and care in order to operate' (Ministry of Education, b) there are a wide range of ECE and other care services currently available. They can be home or centre based or playgroups, rather than education centres. They reflect different perspectives, so that some are more centred on play than others which are more focused on early education. Traditionally in Europe, childcare centres have been a place for children to play, rather than to be educated. They provide 'rich, stimulating experiences within a nurturing social context' but there has been a recent move away from play towards 'introducing young children at the earliest possible stage to the formal skills of literacy and numeracy' (Whitebread et al, 2012).

If schools were to provide 'wrap-around' services on-site, covering before and after-school care, education, and holiday programmes, this would arguably assist parents to participate (or participate more fully) in the labour market. However, the different policy focus in the various elements would need to be clear, and trade-offs may arise. This may include consideration of the extent to which care, play, or education, is the purpose of ECE, and whether a range of service options should be available to parents. Those parents who currently enjoy a level of choice of provider could find that their options reduce if, for example, the number of market participants decreased.

\section{What does quality mean?}

An important issue to consider in any discussion of childcare is quality. For those who believe that the best person to care for a child is its mother, all non-parental childcare is of poor quality, by definition. By providing financial support for non-parental care, it may be argued that government is taking an opposing view, although financial support is also provided for parental care through the Young Parent and Sole Parent Support payments.

The quality of care has implications for a child's development. Research indicates that early care of 'good quality... can also boost early childhood development' (Lawton and Thompson, 2013:5) and 'children stand to gain much more where the quality of provision is 
higher' (Gambaro et al, 2014:1). In this context, 'quality' can mean 'settings in which adults interact with children in a responsive, sensitive and stimulating way' (Gambaro et al, 2014:1). It is also frequently taken to mean care being provided by 'highly trained staff' (Ben-Galim et al, 2014:1) which is achieved through 'education, training, and qualifications for childcare workers' (Himmelweit et al, 2014:28).

In spite of the general acceptance for a requirement of 'quality', research indicates that it is difficult to determine the quality of the childcare being provided. Quality may be 'not very visible to parents' (Stewart et al, 2014:229) so that parents do not have 'a full sense of the quality of a given provider' (Cooke and Henehan, 2012:6). Supporting this concept, it has been suggested that '( $s$ )ome aspects of care quality can be difficult to observe' (Paull, 2014:22). In New Zealand, a previous study found that 'parents make passive choices of centres rather than actively choosing between alternatives' (Smith and Barraclough, 1997) and that there can be a 'zero relationship between parent satisfaction and the research-based measures of quality (because) parents with children attending the 'worst' centres had the fewest criticisms concerning quality' (May, 2003:317).

An additional layer of complexity arises from potential differences between a government's view of quality and a parent's view. Parents may prioritise 'active play' and a 'pleasant centre ambience' over pedagogical plans and qualified teachers (Plantenga, 2012:70). In

Nevertheless, governments often introduce quality regulation. This comes with the risk that if a standard is 'set too low' it could 'reduce usage' and if it is set 'too high' this may 'raise the cost of care above the level that many parents are willing or able to pay' (Paull, 2012:240). Generally, the types of quality regulation used by governments are 'curriculum, staff qualifications, child-to-staff ratios and inspection and monitoring' (Stewart et al, 2014:225) and New Zealand employs all of these methods.

As in all policy decisions, trade-offs may be required. Government may need to balance the education and care roles of schools, along with parent's requirements and expectations of quality, and those of government. Strong State Sector performance would mean doing 'the right things in the right ways at the right time and they must be affordable' (Treasury). 


\section{Part Two - Funding}

Demand-side and supply-side funding

Research indicates that supply-side funding is more appropriate from a cost perspective for childcare support than demand-led funding because ' $(w)$ here countries have expanded demand-subsidies for parents in childcare markets, costs to parents and the taxpayer have tended to rise rather than fall' (Ben-Galim et al, 2014:7). Demand-led funding for childcare is generally some form of tax relief, either by way of deduction or credit, or a cash payment to parents. Supply-side funding involves the government either making payments directly to the childcare provider, or running the childcare facilities itself and 'countries that tend to achieve better value for money tend to rely on supply-side measures' (Ben-Galim et al, 2014:31).

Overall, research indicates that 'markets do not work well in childcare, and that affordable and accessible pre-school childcare and nursery is best secured through predominantly supply-funded and strategically commissioned services' (Ben-Galim et al, 2014:7). In Australia, the Productivity Commission recently confirmed the efficiency of supply-side funding tied to 'quality criteria and eligibility requirements for use of the services' (Australian Government Productivity Commission, 2014:507), even though they continue to support the demand-based services currently in place. In New Zealand, funding consists largely of supply-side measures, an approach which would be considered optimal.

\section{Targeting}

In terms of formal ECE, it is widely accepted that 'children from deprived backgrounds benefited most from this type of provision' (Ben-Galim et al, 2014:14). However, we noted previously that children from disadvantaged groups often have lower than average participation rates in ECE (Salvation Army, Education Counts) and may not access their free entitlements (Ben-Galim et al, 2014:40).

In New Zealand, only a limited amount of childcare expenditure is targeted, with the majority of funding allocated to the 20 hours ECE program. Calls have been made to increase expenditure 'directed at the bottom socio-economic groups as a priority' (Salvation Army, 2011:37) as '(b)roader and more targeted early intervention...may more effectively 
address inequities in early childhood development' (Paull, 2012:30). Recent research has confirmed that cost is an important factor as 'labour force participation among mothers of pre-school children is sensitive to childcare costs' (Ministry of Women's Affairs, b). The ECE Participation Programme for Māori and Pasifika children has been discussed earlier in this paper and further targeting options could be to provide additional support for this programme and/or reprioritise childcare subsidies for those on higher incomes. An increase in targeting should arguably be an area for future policy consideration.

\section{Part Three - Informal childcare}

Informal childcare is that provided by family, particularly grandparents and older siblings, and friends. Statistics New Zealand capture the time individuals spend providing informal childcare in the Time Use Survey. The latest report indicates that $50 \%$ of siblings care for younger children. In terms of grandparents, $24 \%$ of over 65 year olds care for a child not living with them and $91 \%$ of grandmothers, living in same house, care for grandchildren. This makes being cared for by grandparents the most common informal childcare arrangement (Statistics New Zealand, 2013). A similar message had previously been reflected in the most recent New Zealand Childcare Survey with 31.3\% of pre-school children receiving care from a grandparent (Statistics New Zealand, 2010:3).

\section{Grandparents}

Within Māori families, grandparents often participate in the care of mokopuna and their 'availability of grandparents as caregivers for working parents is therefore critical for supporting whanau' (Families Commission, 2012). Grandparents provide childcare for a variety of reasons. In $58 \%$ of cases it was to allow the parents to participate in paid work, but sometimes it was to provide them with a night's sleep (Families Commission, 2010:69, 68).

In New Zealand, the government does not support grandparents who provide childcare but internationally there is some precedent for doing so. In Australia, ACT public servants can take up to 52 weeks leave without pay over a three-year period to care for a child until its third birthday (Australian Capital Territory government, 2008). They do not have to be related to the child for whom they are caring. In Portugal, a financial allowance can be paid to grandparents who look after a sick grandchild or who live together with their grandchild whose mother is 16 or younger and in the UK, National Insurance credits are 
available towards the basic state pension for grandparents who look after a child under 12 so that parents can work (Grandparents plus, 2010:7).

Availability of formal care

Informal childcare may be used because formal childcare is unavailable, particularly if parents work non-standard hours. In New Zealand, research has highlighted 'the stress associated with organising childcare arrangements and working unpredictable and unusual hours' (Families Commission, 2008a:8). Parents raised the difficulty in finding childcare 'in the evening (when) you want to go to work' (Families Commission, 2008b:25). Although this lack of service could be a result of thin demand, it could also reflect what has been described as 'middle-class capture' (Bertram, 1988:1), whereby childcare service providers (and potentially policy makers) assume standard hours of work and access to private transport.

However, the use of informal childcare may also be the parent's choice. It has been noted that 'many parents prefer informal carers over formal sources of childcare because they are seen as trustworthy, more likely to have shared values with the parents and more flexible' (Paull, 2012:22).

\section{Summary}

This paper has collated the range of current government support for childcare, including cost, so that a complete picture is available to academics and policy makers. The question for consideration is whether these services are efficient and effective, and meet the current needs of parents, or whether any change is required.

In future policy design, it will be necessary to balance the nature of parent's requirements and expectations with the intentions of government in providing 'childcare'. This may include consideration of the extent to which care and play, or education, is the purpose of ECE, and whether a range of service options should be available to parents for pre-school age children. It may also require analysis of the role of schools (and government funding) in the provision of before and after-school care, and holiday programmes. Finally, the application of government support should be considered, to determine whether State Sector performance would be enhanced through increased targeting. 


\section{Appendix 1 - Types of funding and cost}

Technical notes:

a) Vote Revenue - Estimates of Appropriations 2014/15

b) Vote Social Development - Estimates of Appropriations 2014/15 - Social Development \& Housing

c) Vote Education - Estimates of Appropriations 2014/15 - Education \& Science Sector 2014/15

d) Vote Education - Estimates of Appropriations 2014/15 - Education \& Science (pro-rated)

e) www.educationcounts.govt.nz - Operational and Salaries funding x Number of students

\begin{tabular}{|c|c|c|c|}
\hline Type of childcare & $\begin{array}{l}\text { Agency / } \\
\text { People }\end{array}$ & \begin{tabular}{|l|} 
Cost \\
$(2014 / 15)$
\end{tabular} & Comment \\
\hline Paid parental leave & IR & $\begin{array}{l}\$ 176 \text { million } \\
\text { a) }\end{array}$ & $\begin{array}{l}25,599 \text { recipients in } \\
2013 / 14 \text { ( } 212 \text { men). } \\
\text { Recently between } 24-27,000 \\
\text { recipients. }\end{array}$ \\
\hline $\begin{array}{l}\text { State care and } \\
\text { protection - CYF }\end{array}$ & MSD & $\begin{array}{l}\$ 362 \text { million } \\
\text { b) }\end{array}$ & $\begin{array}{l}\text { Approximately } 5,000 \\
\text { children. Slightly overstated } \\
\text { only part will be care costs. }\end{array}$ \\
\hline $\begin{array}{l}\text { Unsupported Child } \\
\text { / Orphan's Benefit }\end{array}$ & MSD & $\begin{array}{l}\$ 128.398 \text { million } \\
\text { b) }\end{array}$ & \\
\hline $\begin{array}{l}\text { Child Disability } \\
\text { Allowance }\end{array}$ & MSD & $\begin{array}{l}\$ 83.830 \text { million } \\
\text { b) }\end{array}$ & \\
\hline $\begin{array}{l}\text { Young Parent } \\
\text { Payment }\end{array}$ & MSD & $\begin{array}{l}\text { \$38.858 million } \\
\text { b) }\end{array}$ & \\
\hline $\begin{array}{l}\text { At home parent - } \\
\text { Sole Parent Support }\end{array}$ & MSD & $\begin{array}{l}\$ 1.243 \mathrm{bn} \\
\text { b) }\end{array}$ & \\
\hline $\begin{array}{l}\text { At home parent - } \\
\text { Working for } \\
\text { Families }\end{array}$ & IR & $\begin{array}{l}\$ 1.966 \text { bn } \\
\text { a) }\end{array}$ & \\
\hline $\begin{array}{l}\text { Working for } \\
\text { Families } \\
\text { In Work Tax Credit }\end{array}$ & IR & $\begin{array}{l}\$ 494 \text { million } \\
\text { a) }\end{array}$ & $\begin{array}{l}\text { Only paid to working } \\
\text { parents, so dual purpose, not } \\
\text { just for care }\end{array}$ \\
\hline $\begin{array}{l}\text { At home parent - } \\
\text { Jobseeker Support }\end{array}$ & MSD & $\begin{array}{l}\$ 1.647 \text { billion } \times 1 / 6= \\
\$ 0.274 \text { bn. } \\
\text { b) }\end{array}$ & $\begin{array}{l}\text { Total } 121,000 \text { Jobseeker } \\
\text { recipients, } 1 / 6^{\text {th }} \text { have } \\
\text { children. }\end{array}$ \\
\hline $\begin{array}{l}\text { Childminder - } \\
\text { Informal }\end{array}$ & $\begin{array}{l}\text { Grand- } \\
\text { parents }\end{array}$ & $\mathrm{n} / \mathrm{a}$ & $\begin{array}{l}\text { No cost as NZ Super } \\
\text { payments would not reduce } \\
\text { if childcare was reduced or } \\
\text { removed but care can reduce } \\
\text { their availability for paid } \\
\text { work }\end{array}$ \\
\hline $\begin{array}{l}\text { Childminder - } \\
\text { Informal }\end{array}$ & $\begin{array}{l}\text { Siblings, } \\
\text { friends, } \\
\text { other }\end{array}$ & $\mathrm{n} / \mathrm{a}$ & $\begin{array}{l}\text { No cost for children and cost } \\
\text { for adults captured } \\
\text { elsewhere }\end{array}$ \\
\hline
\end{tabular}




\begin{tabular}{|c|c|c|c|}
\hline $\begin{array}{l}\text { Childminder - } \\
\text { Formal }\end{array}$ & $\begin{array}{l}\text { Private } \\
\text { or NFP }\end{array}$ & $\mathrm{n} / \mathrm{a}$ & $\begin{array}{l}\text { Some NFP could receive } \\
\text { government support in form } \\
\text { of charitable status, no direct } \\
\text { funding provided }\end{array}$ \\
\hline $\begin{array}{l}\text { Early Childhood } \\
\text { Education (ECE) }\end{array}$ & $\begin{array}{l}\text { MoE and } \\
\text { MSD }\end{array}$ & $\begin{array}{l}\$ 1.583 \mathrm{bn} \\
\text { c) }\end{array}$ & $\begin{array}{l}\text { Includes } 20 \text { hours ECE, ECE } \\
\text { and childcare subsidies, } \\
\text { equity fund, participation } \\
\text { and support programmes }\end{array}$ \\
\hline $\begin{array}{l}\text { After-school care } \\
\text { OSCAR } \\
\text { operating costs } \\
\text { OSCAR subsidy }\end{array}$ & MSD & $\begin{array}{l}\$ 17 \text { million } \\
\$ 42.238 \text { million* } \\
\text { b) }\end{array}$ & $\begin{array}{l}\text { Establishment and operating } \\
\text { costs of OSCAR programmes. } \\
\text { Paid on behalf of parents } \\
\text { *unaudited figure }\end{array}$ \\
\hline $\begin{array}{l}\text { Childcare } \\
\text { Assistance }\end{array}$ & MSD & $\begin{array}{l}\$ 140.546 \text { million } \\
\text { b) }\end{array}$ & $\begin{array}{l}\text { Childcare Assistance } \\
\$ 182.784 \mathrm{~m} \text { in total, which } \\
\text { includes Childcare Subsidy } \\
\text { (shown separately above). }\end{array}$ \\
\hline $\begin{array}{l}\text { School Property } \\
\text { Portfolio } \\
\text { Management } \\
\text { Integrated Schools } \\
\text { Property }\end{array}$ & $\mathrm{MoE}$ & $\begin{array}{l}\$ 99 \text { million } \\
\text { d) } \\
\$ 45.45 \mathrm{~m} \\
\text { d) }\end{array}$ & $\begin{array}{l}\text { Education capital } \\
\text { expenditure. } \\
\text { Both amounts pro-rated to } \\
\text { only show children under } 14 \text {. } \\
\text { Education capital } \\
\text { expenditure }\end{array}$ \\
\hline $\begin{array}{l}\text { Interventions for } \\
\text { Target Student } \\
\text { Group } \\
\text { Special Needs } \\
\text { Support }\end{array}$ & $\mathrm{MoE}$ & $\begin{array}{l}\$ 231 \text { million } \\
\text { d) }\end{array}$ & $\begin{array}{l}\text { Special needs funding. } \\
\text { Children educated within } \\
\text { mainstream schools so } \\
\text { education focus. }\end{array}$ \\
\hline $\begin{array}{l}\text { Boarding } \\
\text { allowances and } \\
\text { scholarships }\end{array}$ & MoE & $\begin{array}{l}\text { \$11.4 million } \\
\text { d) }\end{array}$ & $\begin{array}{l}\text { Puawaitanga and private } \\
\text { school scholarships }\end{array}$ \\
\hline School transport & MoE & $\begin{array}{l}\$ 126 \text { million } \\
\text { d) }\end{array}$ & $\begin{array}{l}\text { Removes barrier to use of } \\
\text { childcare / education }\end{array}$ \\
\hline $\begin{array}{l}\text { Years 1-8 } \\
\text { Primary and } \\
\text { intermediate school }\end{array}$ & MoE & $\begin{array}{l}\$ 2.8 \mathrm{bn} \\
\mathrm{e})\end{array}$ & $\begin{array}{l}\text { Primary focus is education } \\
\text { but care element included }\end{array}$ \\
\hline $\begin{array}{l}\text { Years } 9-10 \\
\text { Secondary school }\end{array}$ & MoE & $\begin{array}{l}\text { \$807 million } \\
\text { e) }\end{array}$ & $\begin{array}{l}\text { Primary focus is education. } \\
\text { Up to year in which children } \\
\text { turn } 14 .\end{array}$ \\
\hline Grand Total & & $\$ 10.9$ billion & \\
\hline
\end{tabular}




\section{Appendix 2}

Figure 3 - Cost of childcare funding

Technical notes:

Welfare payment includes CDA, YPP, SPS, WFF and JSS. State care includes CYF, US and OB. Education includes SPPM, ISP, ITSG, SNS, BA\&S, ST and Years 1-10 costs.

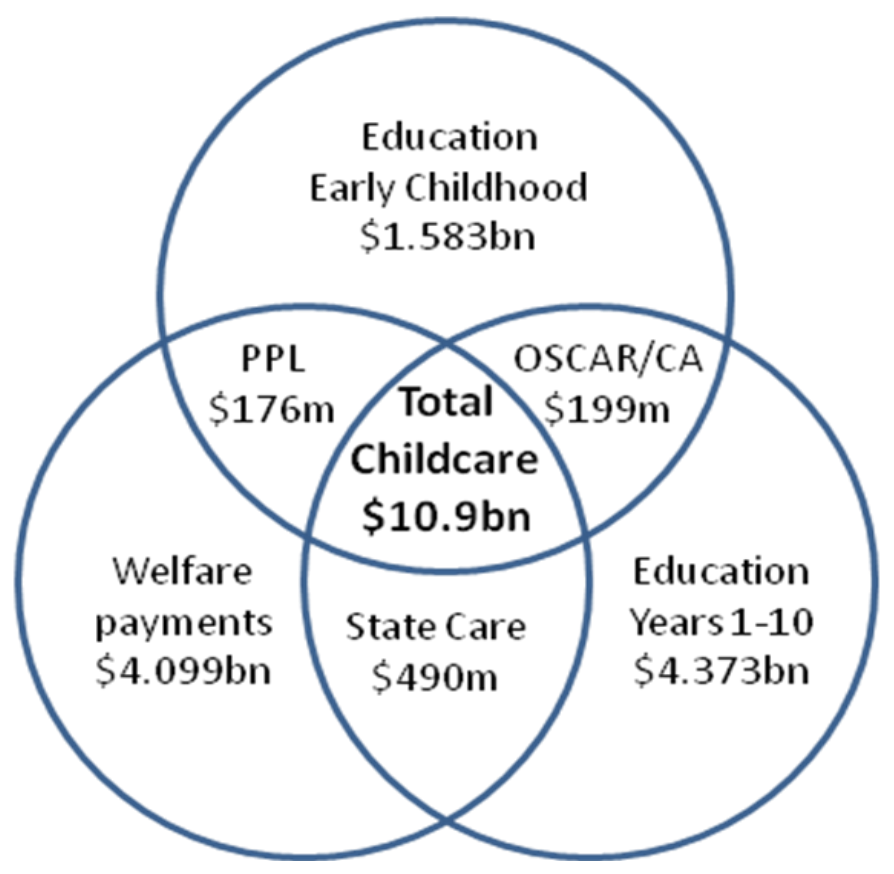

Figure 4 - Appropriations which include childcare expenditure

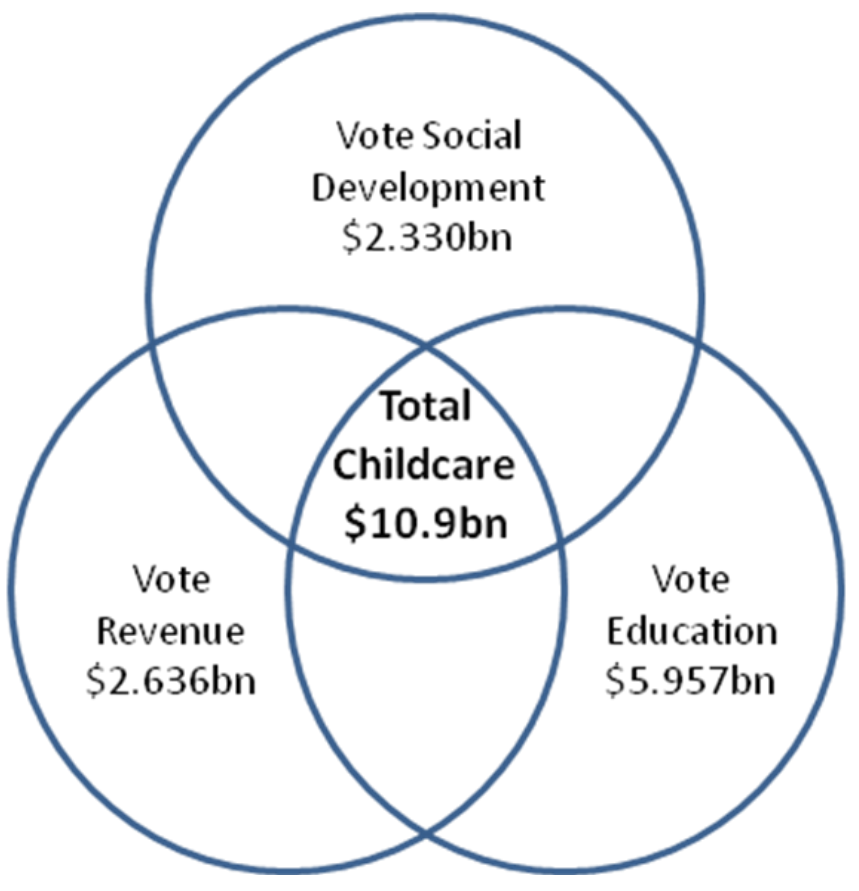




\section{References}

Australian Capital Territory government (2008) Benefits for mature age ACT public servants. Retrieved in September 2014: http://info.cmcd.act.gov.au/archivedmedia-releases/media54bc.html?v=6993\&s=191.

Australian Government Productivity Commission (2014). Childcare and Early Childhood Learning. Productivity Commission Draft Report, July 2014.

Ben-Galim, Dalia with Pearce, Nick and Thompson, Spencer (2014). No More Baby Steps. A Strategy for Revolutionising Childcare. Institute for Public Policy Research, UK.

Bertram, Geoff (1988). "Middle-Class Capture": A Brief Survey. Retrieved in November 2014: http://www.geoffbertram.com/publications/

Cooke, G. and Henehan, K. (October 2012). Double Dutch - The case against deregulation and demand-lend funding in childcare. Institute for Public Policy Research, UK.

Education Counts, a. Website - Home - Statistics - Early Childhood Education Participation. Retrieved in November 2014:

http://www.educationcounts.govt.nz/statistics/ece2/participation

Education Counts, b. Website - Home - Statistics - Early Childhood Education - ECE Indicators - Participation in early childhood education. Retrieved in November 2014: http://www.educationcounts.govt.nz/statistics/ece2/ece-indicators/1923

Ellingsaeter, Anne Lise and Gulbrandsen, Lars (2007). Closing the Childcare Gap: The Interaction of Childcare Provision and Mothers' Agency in Norway. Journal of Social Policy, Volume 36, Issue 4, pp649-669.

European Commission (2012). Female Labour Market Participation.

Families Commission (September 2008a). Juggling Acts. How parents working non-standard hours arrange care for their pre-school children. Research report number 6/08.

Families Commission (2008, b). New Kiwis, diverse families. Migrant and former refugee families talk about early childhood care and education needs. Report number 7/08.

Families Commission (February 2010). Changing Roles. The pleasures and pressures of being a grandparent in New Zealand. Research report number 1/10.

Families Commission (September 2012). Tupuna - Nga Kaitiaki Mokopuna. A resource for Māori grandparents. Research report number 05/12.

Flynn, Sophie and Fromm, Andrea (2012). Labour Underutilisation in New Zealand. Labour, Employment and Work Conference 2012.

Gambaro, L., Stewart, K. and Waldfogel, J. (2014) (Editors). An Equal Start? Providing quality early education and care for disadvantaged children. Bristol, UK: Policy Press. 
Goldman Sachs (2011). Economics. Closing The Gender Gap: Plenty Of Potential Economic Upside. Research Report.

Grandparents plus (June 2010). Grandparenting in Europe. Institute of Gerontology at King's College London.

Hall, Simon (2008). Underutilised Labour: More Than The Unemployed? Labour, Employment and Work in New Zealand 2008.

Himmelweit, Jacob Mohun, Coote, Anna \& Hough, Juliette (2014). The value of childcare. Quality, cost and time. New Economics Foundation, UK.

Jaumotte, Florence (2003). Female labour force participation: Past trends and main determinants in OECD countries. OECD, Economic Department Working Papers No.376

Lawton, Kayte and Thompson, Spencer (2013). Tackling in-work poverty by supporting dual-earning families. Joseph Rowntree Foundation Report.

Lloyd, Eva and Penn, Helen (2010) (Editors) Childcare markets: Can they deliver an equitable service? UK: Policy Press.

May, Helen (2003). Concerning Women Considering Children. Battles of the Childcare Association 1963-2003. Wellington, New Zealand: New Zealand Childcare Association.

Ministry of Education, a. Parents. Early Years. Retrieved in September 2014: http://www.minedu.govt.nz/Parents/EarlyYears/HowECEWorks/20HoursECE/Inf oGuide4Parents/General.aspx

Ministry of Education, b. ECE Lead. Programmes and Initiatives. ECE Participation Programme. Retrieved in November 2014: http://www.lead.ece.govt.nz/ProgrammesAndInitiatives/ECEParticipationProgram $\underline{\text { me.aspx }}$

Ministry of Education, c. Parents and whānau. Early years. Retrieved in November 2014: http://www.minedu.govt.nz/Parents/EarlyYears.aspx

Ministry of Social Development (2003). Reducing Inequalities: Next Steps. Cabinet Social Development Committee Paper. Retrieved in November 2014:

https://www.msd.govt.nz/about-msd-and-our-work/work-programmes/policydevelopment/reducing-inequalities/index.html

Ministry of Women's Affairs (August 2013). Building back better: Utilising women's labour in the Canterbury recovery. A snapshot of the research findings. Retrieved in November 2014:

http://mwa.govt.nz/documents/building-back-better-utilisingwomen $\%$ E2\%80\%99s-labour-canterbury-recovery-2013

Ministry of Women's Affairs, a. New Zealand women. Retrieved in September 2014: http://mwa.govt.nz/new-zealand-women 
Ministry of Women's Affairs, b. Childcare. Retrieved in December 2014: http://mwa.govt.nz/our-work/economic-independence/paid-and-unpaidwork/childcare

OECD (2012). Closing the Gender Gap: Act Now. OECD Publishing. Retrieved in September 2014: http://dx.doi.org/10.1787/9789264179370-en

Oscar Network (South Island only) http://www.oscarnetwork.org.nz/

Parliamentary Counsel Office, New Zealand Legislation. Retrieved in November 2014: http://www.legislation.co.nz/act/public/1981/0113/latest/DLM53348.html?searc h=ts act\%40bill\%40regulation\%40deemedreg Summary+Offences+Act+ resel 25 $\underline{\mathrm{a} \& \mathrm{p}=1}$

Paull, Gillian (2012). Childcare markets and government intervention. In Lloyd, Eva and Penn, Helen (Editors) Childcare markets: Can they deliver an equitable service? (pp227-246). UK: Policy Press.

Paull, Gillian (2014). Can government intervention in childcare be justified? Institute of Economic Affairs, UK.

Plantenga, Janneke (2012). Local providers and loyal parents: competition and consumer choice in the Dutch childcare market. In Lloyd, Eva and Penn, Helen (Editors) Childcare markets: Can they deliver an equitable service? (pp63-77). UK: Policy Press.

Plantenga, Janneke \& Remery, Chantal (2013). Childcare services for school age children. A comparative review of 33 countries. European Commission Directorate-General for Justice.

Schultz, Vicki (2000). Life's Work. Columbia Law Review, Volume 100, Number 7, (November 2000) p1881-1964.

Safe Kids in Daily Supervision (Selected national locations) http://www.skids.co.nz/

Salvation Army, The (2011). Monopoly games in the nursery. Community, Inequalities and Early Childhood Education. Social Policy and Parliamentary Unit. Retrieved in November 2014: http://www.salvationarmy.org.nz/research-media/social-policyand-parliamentary-unit/reports/monopoly-games-in-the-nursery

Smith, Anne B. and Barraclough, Shanee J (1997). Quality childcare: do parents choose it? Early Childhood Folio 3.

Statistics New Zealand (2009). New Zealand Childcare Survey. Retrieved in December 2014:

http://www.stats.govt.nz/browse_for_stats/people_and_communities/Children/chil dcare-survey-info-releases.aspx

Statistics New Zealand (2013). Caring for children: Findings from the 2009/10 Time Use Survey. 
Statistics New Zealand (2014) Household Labour Force Survey: June 2014 quarter. Retrieved in November 2014: http://www.stats.govt.nz/browse for stats/incomeand-

work/employment and unemployment/HouseholdLabourForceSurvey HOTPJun14 qtr.aspx

Stewart, K., Gambaro, L., Waldfogel, J. and Rutter, J. (2014). Common challenges, lessons for policy. In Gambaro, L., Stewart, K. and Waldfogel, J. (Editors). An Equal Start? Providing quality early education and care for disadvantaged children (pp219-243). Bristol, UK: Policy Press.

Summers, Anne (2013, May 20). Abbott's baby bonus in disguise. Sydney Morning Herald, Australia. Retrieved in August 2014: http://www.smh.com.au/federalpolitics/political-opinion/abbotts-baby-bonus-in-disguise-20130517-2jrmf.html

Sustainable Business Council. Innovative childcare project to be developed by business and community leaders. Retrieved in December 2014:

http://www.sbc.org.nz/news/national/innovative-childcare-project

Thompson, Spencer \& Ben-Galim (2014). Childmind the gap. Reforming childcare to support mothers into work. Institute for Public Policy Research, UK.

Treasury. A Higher Performing State Sector. Retrieved in December 2014: http://www.treasury.govt.nz/statesector/performance

Vote Education (2014). The Estimates of Appropriation 2014/15 - Education and Science Sector.

Vote Revenue (2014). The Estimates of Appropriation 2014/15 - Finance and Government Administration Sector.

Vote Social Development (2014). The Estimates of Appropriation 2014/15 - Social Development and Housing Sector.

Waring, Marilyn (1988). Counting for nothing: What men value and what women are worth. New Zealand: Allen \& Unwin.

Whitebread, Dr David with Basilio, M., Kuvalja, M. and Verma, M. (2012). The importance of play. A report on the value of children's play with a series of policy recommendations. Retrieved December 2014:

http://www.importanceofplay.eu/promoting-play/texts/article/the-importance-ofplay-a-report-on

Women's Business Council (2014). Maximising women's contribution to future economic growth. One year on - June 2014. UK: Government Equalities Office.

World Economic Forum (2013). The Global Gender Gap Report 2013 - Insight Report.

Young, Claire (1994). Child Care - A Taxing Issue? McGill Law Journal, Volume 39, pp539567. 